\title{
De Patricia Williams A Patricia Collins: Raça, Crítica E
} Feminismo

From Patricia Williams to Patricia Collins: Race, Critique, and Feminism

\section{Ana Pontes-Saraiva'}

1 Universidade Federal do Agreste de Pernambuco, Garanhuns, Pernambuco, Brasil. Email: professoraanapontes@gmail.com. ORCID: https://orcid.org/0000-0002-9345-7952.

\section{Ciani Sueli das Neves ${ }^{2}$}

2 Grupo de Pesquisa Asa Branca Criminologia, Recife, Pernambuco, Brasil. E-mail: cianisueli@gmail.com. ORCID: https://orcid.org/0000-0002-4635-5582.

Artigo recebido em 7/05/2021 e aceito em 10/05/2021.

\section{$(\mathrm{cc})$ EY}

This work is licensed under a Creative Commons Attribution 4.0 International License. 
Resumo

Traçar caminho dialógico entre Patricia Hill Collins, como elemento do pensamento feminista negro para superar opressões racistas, patriarcais, classistas e heterossexistas, com as reflexões realizadas por Patricia J. Williams ao articular-se com os Critical Legal Studies (CLS), enfrentando realidades invisibilizadas com a Critical Race Theory (CRT) é o escopo deste artigo. Analisar todos esses "passos que vêm de longe" nos faz compreender que o arcabouço teórico de Williams, detentora de trocas significativas na epistemologia feminista negra, foi rico o suficiente para permitir qualidade em seu olhar teórico e refletir sobre os CLS e a acuidade de suas contribuições para a CRT. Patricia Hill Collins foi escolhida pela contemporaneidade e similitudes de articulações teóricas com Williams. Sua visão do pensamento feminista negro como teoria social crítica, em um processo consciente contra formas diversificadas de opressão, leva a compreender a influência sobre Patricia Williams na crítica sobre a troca das demandas por direitos por demandas por necessidades, ideia bem construída por Collins. $O$ artigo também busca esclarecer como essas reflexões influenciaram e podem permanecer fortalecendo a epistemologia feminista interseccional brasileira.

Palavras-chave: Feminismo negro; Patricia J. Williams; Patricia Hill Collins; interseccionalidade; Critical Race Theory; Critical Legal Studies.

\section{Abstract}

It is the aim of this paper to build a dialogical path between Patricia Hill Collins as member of the Black feminist thought, in order to overcome racist, patriarchal, classist and heterosexist oppressions, and Patricia J. Williams' reflections when taking part of the Critical Legal Studies (CLS) and facing realities made invisible by the Critical Race Theory (CRT). To analyze all those "steps that came from afar" allows us to understand that Williams' critical framework, which produced relevant exchanges in Black feminist epistemology, was rich enough so as to generate a qualified theoretical look and to examine the CLS and the precision of its contributions to CRT. Patricia Hill Collins was chosen for the contemporaneity and similarities of her theoretical articulations with Williams. Her vision of the Black feminist thought as social critical theory, in a conscious process against diversified oppression forms, makes us comprehend the influence upon Patricia Williams in her criticism on the replacement of claims for rights by claims for needs as an evidence of the complex and intense exchanges of Black feminist 
epistemology, in which Collins is a main character. This paper also seeks clarify how those thoughts might contribute to strenghten Brazilian Black feminist epistemology.

Keywords: Black feminism; Patricia J. Williams; Patricia Hill Collins; intersectionality; Critical Race Theory; Critical Legal Studies. 
"O mundo ao nosso redor cresce e nós vamos diminuindo. Nossas vozes, que outrora refletiam a primavera, passam a ser silenciadas de maneira tão violenta que acabamos esquecendo que possuímos uma voz e não precisamos da de ninguém para definir quem somos".

Patricia Hill Collins, Black Feminist Thought

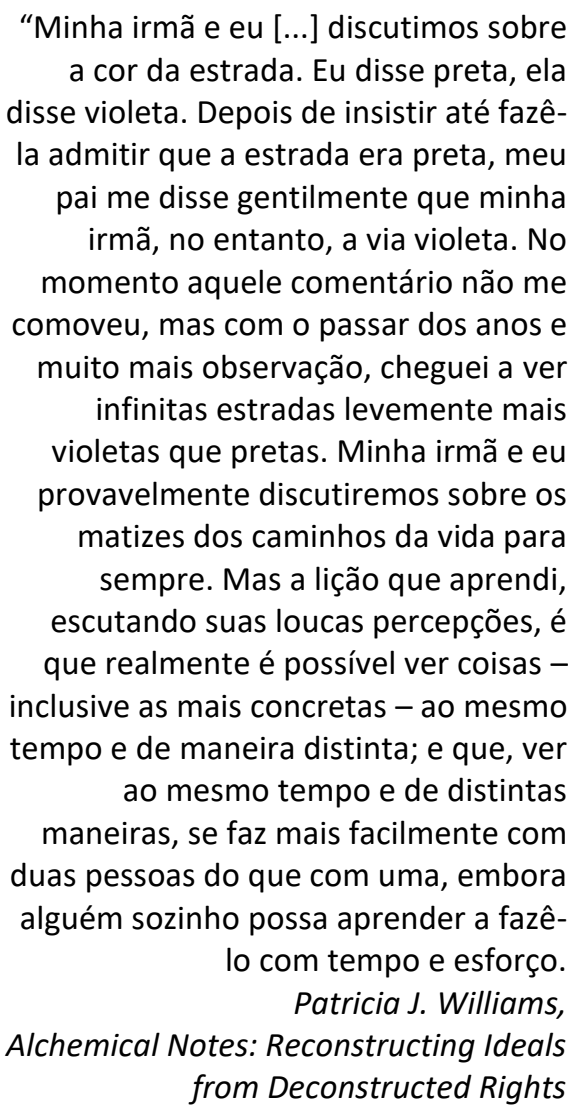

\section{Notas introdutórias}

As contribuições de Patricia Hill Collins (1948-) expõem, entre outras reflexões, o pensamento feminista negro amparado na interseccionalidade de raça, gênero e classe como ferramenta metodológica de análise. Isso é especialmente interessante porque oferece um olhar sobre os elementos na incidência político-jurídico-cultural para superar opressões racistas-patriarcais-classistas-heterossexistas. A obra de Collins tem recebido, ao longo dos anos, crescente atenção, embora ainda não tenha atingido reconhecimento compatível com sua qualidade técnica. Como observou a própria teórica, é eloquente que se tenham passado mais de trinta anos para que fosse publicado no Brasil seu livro Pensamento feminista negro, a despeito do intenso tráfego de autores e autoras estadunidenses no Brasil. Hill Collins notou que tanto obras acadêmicas como literárias 
de mulheres negras são pouco traduzidas ou demoram muito para chegar a outras línguas, por uma razão pouco evidente para alguns: a atitude proposital daqueles no poder - e mulheres negras não estão no comando do que é publicado - tanto em jornais, quanto em editoras, muito menos na política. Caso mulheres negras comandassem algumas dessas instâncias, talvez houvesse mais trabalhos intelectuais representativos. Todavia, como é notável, o que acontece comumente é que uma autora negra precisaria ser vista como excepcional para ser dissociada do que é "comum" e ser reconhecida como exceção. ${ }^{1}$ Não por acaso, na mesma entrevista, Patricia Hill Collins assinala que a celebrização da biografia de Michelle Obama demonstra essa combinação de "excepcionalidade" e celebridade, reforçando o sexismo, o classismo e o racismo².

Nesta abordagem, desejamos um pouco mais do que ampliar a lista de artigos que publiciza a obra de duas teóricas contemporâneas: queremos percorrer a trajetória das contribuições de Patricia Collins ligando-a a um caminho dialógico com as reflexões de Patricia Williams e estabelecendo pontos de contato dentro do feminismo interseccional. Em especial, ante a crítica da instrumentalidade teórica elaborada dos Critical Legal Studies (CLS), que tanto ensaiaram novos caminhos para enfrentar a realidade jurídicopolítica hegemônica como operaram as contranarrativas que ressituaram pessoas em suas particularidades e contingências. Mais especificamente, nos interessam as contribuições para enfrentar realidades invisibilizadas mediante o componente raça, destacado por Williams, e da defesa da interseccionalidade trabalhada por Hill Collins. Naturalmente, pensamos sobre como essas contribuições ganham significado na realidade brasileira.

A escolha não é sem razão: Patricia J. Williams (1951-), doutora pela Harvard Law School, elabora produções interdisciplinares em que analisa gênero, raça e classe no pensamento jurídico a partir de perspectiva pessoal desde a metade da década de 1980.Patrícia Williams já apresenta uma visão interseccional, posto que este olhar é muito

1 "Feminismo precisa ser cuidadoso para não perder o sentido". Entrevista de Patricia Collins para o lançamento de "Pensamento Feminista Negro" no Brasil, publicada em 27.10.2019. Por Andréa Martinelli. Disponível em: $<$ https://www.geledes.org.br/feminismo-precisa-ser-cuidadoso-para-nao-perder-sentido-diz-patricia-hillcollins/> Acesso em 3 de janeiro de 2021.

2 “Nós não deveríamos precisar ser a Michelle Obama para que nossos livros sejam publicados. Veja como ela é excepcional! Mas isso é a combinação do racismo, do sexismo e do classismo. E basicamente nos envia de volta às imagens de controle: mulheres negras não se encaixam no perfil daqueles que deveriam ser espertos, competentes e talentosos. Você precisa provar a si mesma muito mais do que aqueles que tomam tais coisas como garantidas". Idem. 
mais intencional que um rótulo acadêmico: ainda que não use o nome, Williams já se mostra interseccional desde "Alchemy of Races". Integrante de uma das correntes que floresceram com o arsenal teórico elaborado pelos crits - mas não apenas, como aqui defendemos - enfrentou realidades das quais outros não se aperceberam. Defensora da teoria crítica da raça, escola de pensamento jurídico que evidencia a raça como determinante fundamental do sistema jurídico americano, Williams é uma das principais representantes da corrente teórica denominada Critical Race Theory (CRT), que contribuiu com uma das mais marcantes e bonitas dissonâncias em relação à corrente dominante dos Critical Legal Studies (CLS). Patricia Williams desenha um caminho que traz inegáveis repercussões epistemológicas quando desta contribuição. E um dos pontos mais fulgurantes compreende sua capacidade de destacar como o racismo se aclimata nas exclusões várias, que traz o entendimento contemporâneo que permite a compreensão, por exemplo, da supressão de visibilidade de pessoas com deficiência negras ou do movimento queer negro dentro das lutas coletivas negras.

Uma das situações se levanta, portanto, quando intelectuais negras como Patricia Collins conduziram a discussão geral do pensamento feminista negro como teoria social crítica, em processo consciente de desmascarar racismos e demais formas de opressão com ele articuladas, chamando-nos a olhar através do espelho que permite ver nossa verdadeira face como sociedade. Contemporâneas, não há tanta luz sobre um fato marcante: ambas influenciaram-se de formas diversas com seus trabalhos, e essa troca se multiplica em pequenas e belas minas d'água fascinantes da epistemologia do pensamento feminista negro.

O olhar pronunciado de Patricia Hill Collins reverbera em Patricia Williams em diversos momentos, em especial quando esta alimenta a Critical Race Theory na posição de que não é razoável preferir substituir "demandas por direitos" por outras que focassem "necessidades" - como observou em crítica a teses dos CLS -, pois negras e negros teriam sua vulnerabilidade protegida e obteriam possibilidade de fugir de estereótipos por meio da linguagem dos direitos. ${ }^{3}$

Essas contribuições são parte de um legado precioso, que permite trilhar percurso que nos toca, como brasileiras, mais particularmente. Advogamos, por óbvio, a

3 NERIS, Natália. Um efeito alquímico: sobre o uso do discurso dos direitos pelas/os negras/os. Revista Direito e Práxis. Vol. 9, n. 1, Rio de Janeiro; Jan./mar. 2018. Disponível em <https://is.gd/Jur0061> ou <https://doi.org/10.1590/2179-8966/2017/25487>. Acesso em 2 jan. 2021. 
necessidade de temperança com a realidade afro-brasileira. É fato que tanto a herança dos CLS como da CRT banhadas pelo feminismo negro estadunidense, como escolhemos analisar, tem particularidades. Portanto, não faria sentido ser transposto "acriticamente" 4 pelos movimentos e organizações críticos do Direito, como não devem ser pelos movimentos de mulheres negras no Brasil. Não perdemos de vista, dessa maneira, que nossas hipóteses ao investigar as aproximações intelectuais entre ambas se manterá alerta a este aspecto, sobretudo como essas ponderações podem contribuir com nossa realidade.

Usando o método de abordagem dedutivo e análise bibliográfico-documental, mas não apenas, seguiremos nessa empreitada. Sob o prisma ancestral, optamos pela escolha metodológica traçada por Lélia Gonzalez e partilhada por Patricia Hill Collins de ressaltar a presença das que iniciaram antes e das que virão depois. Comprometer-nos com os princípios de ancestralidade e memória como pilares dos princípios ontológicos africanos, sendo as mulheres negras reconhecidas como suas portadoras, é um de nossos focos. Inserimos a busca por pesquisar as "interseccionalidades" entre duas autoras em um olhar também interseccional feminista e observamos como os braços dos "rios" reflexivos de uma deságuam em outra, como se alimentam e como se distanciam.

Jogar mais luz sobre a visão do feminismo negro como epistemologia de referência para valorização e reconhecimento do pensamento das mulheres negras como intelectuais, e como este pensamento deu características únicas à contribuição de Williams aos CLS é o ponto mais largo desse curso d'água que almejamos. Ele não seria diferente a partir de nossa escolha de mulheres que sabem ser rios, âncoras e lemes.

\section{A mesma mátria ${ }^{5}$ imaterial. Para além do prenome, caminhos interseccionais}

É curioso que ambas as autoras tenham recebido um prenome inspirado nos patrícios

\footnotetext{
4 Usamos acriticamente e críticos aqui como forma de reafirmar o que queremos demarcar: nossa intenção é buscar primordialmente um diálogo com as escolas críticas do direito acerca das limitações impostas por suas epistemologias tradicionais, mas que para isso temos ciência de a aproximação com teorias e experiências estrangeiras não podem ser incorporadas de forma integral, e sim considerando os elementos que se lhes permitem adequações aos contextos locais.

5 Apesar de inusual em artigos, gostaríamos de acrescentar um agradecimento especial às felizes trocas em conversa virtual com Júlia Ávila Franzoni e Philippe Oliveira de Almeida . Entre diversas contribuições e provocações a este texto, registramos a expressão "mátria" deste título.
} 
romanos e como essa situação amplia o sentido ao ser dada entre homens ou entre mulheres. No masculino, o prenome significava pertencimento a uma nobreza que se via e se reconhecia como tal. Parte desse reconhecimento se devia a uma condição de cidadania convenientemente negada às mulheres, em especial às pessoas escravizadas.

O mesmo prenome, no feminino, desloca em parte seu sentido: já não se vincula à nobreza, mas à ideia de identificação: a palavra "patrícia" passa a compreender a identificação de pessoas que nasceram na mesma pátria ou são conterrâneas. Essa inspiradora curiosidade alinha os primeiros pontos de Patricia Williams e Patricia Collins em que, como fios, se unem críticas raciais a teóricas feministas no intuito de romper a ideia de particularidade de determinados problemas e injustiças típicos de alguns grupos sociais. Perfilar suas trajetórias acadêmicas e identificá-las reforça a ideia de que "o pessoal é político", buscando evidenciar injustiças relacionadas a raça e gênero.

De braços dados à storytelling, seguem ambas embaladas corajosamente com o rosto à mostra enquanto demarcam o quanto o pessoal é político, bem como que "um galo sozinho não tece a manhã ${ }^{\prime \prime}$. Pois escrever, compartilhar e despertar o "querer saber" constitui enfim um entrelaçamento dos conteúdos percebidos pela diversidade de olhares que permite a tessitura de saberes coletivos. A beleza do trabalho entretecido vai justamente de como Williams vai desenredando várias camadas: traz, por exemplo, o desvelamento da observação que, após a primeira camada mais evidente, de que o feminismo encontra-se restringido ao olhar predominante da mulher branca, mergulha mais fundo nestas linhas ao registrar que a crítica racial precisa ampliar o olhar quando encontra-se limitada à visão do homem negro.

6 Tecendo a manhã (João Cabral de Melo Neto)

Um galo sozinho não tece uma manhã:

ele precisará sempre de outros galos.

De um que apanhe esse grito que ele e o lance a outro; de um outro galo que apanhe o grito de um galo antes e o lance a outro; e de outros galos que com muitos outros galos se cruzem os fios de sol de seus gritos de galo, para que a manhã, desde uma teia tênue, se vá tecendo, entre todos os galos.

E se encorpando em tela, entre todos, se erguendo tenda, onde entrem todos, se entretendendo para todos, no toldo (a manhã) que plana livre de armação. A manhã, toldo de um tecido tão aéreo que, tecido, se eleva por si: luz balão. 
Patricia J. Williams (1951-) ficou conhecida por pertencer à tradição dos Estudos Jurídicos Críticos (CLS), mas acrescendo exatamente a visão dos chamados Estudos Raciais Críticos (CRT), ainda que não somente. Isto porque a tradição da epistemologia feminista negra the permitia um olhar ainda mais amplo. Doutora pela Faculdade de Direito de Harvard, Williams é docente emérita da Universidade de Colúmbia e, atualmente, diretora do Departamento de Direito, Tecnologia e Ética da Universidade Northeastern (2019). Autora de centenas de artigos científicos e jornalísticos com uma consistente diversidade de temas, priorizaremos seus aportes teóricos aos Estudos Jurídicos Críticos, particularmente suas ponderações sobre raça.

Integrando a Segunda Geração dos CLS, que objetivava fortalecer uma crítica sistêmica às instituições jurídicas e à linguagem dos direitos, Williams passou a analisar as instituições do Direito dando centralidade a raça, gênero e classe para interpretação dos meios e fins do sistema jurídico. Foi além, como destacamos, aliando o olhar da epistemologia feminista negra com uma carga de conhecimento de teóricas contemporâneas e anteriores.

Patricia J. Williams não apenas se desloca da Primeira Geração dos CLS, que predominantemente propunha o abandono da linguagem dos direitos por seu caráter conservador e alienante. A teórica aponta as lacunas dessa visão, justificável pelo lugar ocupado por seus proponentes. Williams sugere o resgate dessa linguagem e das reivindicações legais, pois direitos, liberdades e garantias apresentam significâncias e afetam a vida de comunidades e grupos de maneiras desiguais. Para Williams, os direitos possuem importância transformadora e simbólica e um efeito alquímico na vida de grupos historicamente oprimidos que não precisa ser abandonado, mas encontrado em novas formas de tomada de sentido e de apropriação.

Destacam-se como suas mais conhecidas obras: The Alchemy of Race and Rights: A Diary of a Law Professor ["A alquimia da raça e os direitos: diário de uma professora de Direito"] (1991), The Rooster's Egg ["O ovo do galo"] (1995) e Seeing a Color-Blind Future: The Paradox of Race ["Vendo um futuro cego à cor: o paradoxo da raça"] (1997). Apesar da importância de suas rcontribuições para o direito, sob a perspectiva crítica, e consequentemente, para outras áreas permeadas pela interdisciplinaridade, esbarra no obstáculo de que seus escritos começaram a ser traduzidos para o português apenas a partir de 2018. Registre-se que por iniciativa de discentes e docentes estudiosos de seu pensamento e do CLS. 
Os CLS, para além do aspecto discursivo que se antecipou acima, compreendeu um movimento de intervenção política e intelectual de esquerda no campo acadêmico das faculdades de direito norte-americanas da década de 1970. Perdeu fôlego atualmente, mas suas sementes brotaram no pensamento que influencia diversos teóricos e teóricas atuais. A consideração do contexto de surgimento dos CLS é fundamental para que se possam devassar suas teses principais. Nesse momento, o Direito parecia a porta de entrada não apenas de grupos progressistas nas décadas de 1950 e 1960 (a chamada "Era dos Direitos Civis"). Por meio de sua atuação intelectual, Williams analisou uma ruptura deste influxo que terminou por manietar primordiais conquistas nos decênios seguintes, tanto em 1970 como em 1980. E que disseminou pelas faculdades de Direito a discussão sobre o pensamento único, legando às correntes contramajoritárias da reflexão jurídica estratégias de pesquisa bastante valiosas até hoje. Além de uma reação neoliberal estimulada pela queda do muro de Berlim, alguns dos conteúdos "progressivos" foram lamentavelmente manejados por conservadores, aproveitando este movimento de pêndulo que costuma ocorrer em mudanças de paradigmas. Estes conservadores buscaram reagir com estratégias camaleônicas dentro dos espaços duramente conquistados pelas classes que lhes serviam.

Os acontecimentos vivenciados na América do Norte demonstraram que a retórica dos direitos se concentrou na segunda metade do século XX, permanecendo silente sobre o fato de que caucionou avanços nos setores progressistas. Todavia, permitiu o mesmo por setores conservadores, demonstrando que o discurso dos direitos poderia ser impulsionado por grupos divergentes. Demonstrou, em última análise, que "a retórica ou linguagem dos direitos é, portanto, manipulável, negociável” como bem aponta Natália Neris ${ }^{7}$

É nesse caminhar que é aprofundada uma ponderação crítica à razão jurídica norte-americana e suas bases de legitimação, trazendo-Ihe mais radicalidade numa perspectiva de chamar a atenção para os marcadores que raça, gênero e classe viabilizam no campo dos estudos jurídicos críticos e a necessidade de seu reconhecimento e incorporação nas análises e proposições trazidas pela Escola. A compreensão que chegamos a partir dos escritos de Williams é de que o positivismo liberal, o funcionalismo sociológico e a doutrina da interpretação constitucional não alcançam o suporte esperado

7 NERIS, Um efeito alquímico... ob. cit. na nota 4. 
para a garantia que se procura. Mesmo sendo inequívoco que o direito não pode ser reduzido a uma equação política, não é possível, por outro lado, ignorar os fatores que empreendem nesse sentido. O sentido político é visível, inclusive nas interpretações jurídicas, as quais têm consequências distributivas consideráveis. Mais: não se pode negar que o direito se encontra fortemente ligado ao discurso e, como tal, a linguagem dos direitos pode (e geralmente vai, pois não se encontra à parte do mundo real) reforçar alicerces forjados em dominação e sistemas de controles sociais, que terminam por reforçar posições e status quo.

Vale salientar que Kimberlé Crenshaw ${ }^{8}$ - que cunhou o termo 'interseccionalidade' - surge da Teoria Racial Crítica, assim como Patrícia Williams. As duas dialogam desde a década de 1970 e sabemos que Crenshaw grava o conceito como uma crítica, não só ao feminismo "branco", mas, também, aos seus colegas homens da Critical Race Theory. As mulheres negras que pertencem à CRT, desde a década de 1980, denunciam a hipervalorização das experiências dos homens negros, no interior do movimento. Os escritos de Crenshaw e Williams representaram um "giro" interseccional e feminista no interior da CRT, o que permite um diálogo claro mais adiante com as considerações de Collins.

Ambiguidades, lacunas e as inevitáveis dissensões próprias do ordenamento jurídico cooperam cotidianamente para esse resultado criticado. A indeterminação da sistemática jurídica não é apenas uma de suas particularidades: é parte de sua própria textura aberta, por lidar com a delicada matéria dos direitos. Isso não requer, contudo, que optemos pelo caminho facilitado da presunção da neutralidade tão cara ao liberalismo, que convenientemente se fundamenta em princípios para advogar essa ideia como pretensamente segura.

Assim se posicionam críticos e críticas dos CLS. Destaca Natália Neris que é da metade dos anos 1980 em diante que diferentes autores "como Kennedy e Gabel (1984), Tushnet (1984) e Olsen (1984) sustentaram que o discurso dos direitos nas teorias liberais e progressistas seria alienante. ${ }^{\prime \prime}$ Ela observa que um dos trabalhos recentes de Peter Gabel evidencia tal argumento, e destaca pequeno trecho:

8 Kimberlé Williams Crenshaw, defensora dos direitos civis americana e uma das principais estudiosas da teoria crítica da raça, é professora em tempo integral na Faculdade de Direito da UCLA e na Columbia Law School, onde se especializa em questões de raça e gênero.

9 NERIS, Um efeito alquímico... ob. cit. na nota 4. 
[...] o problema da lei não era que ela fosse indeterminada e, portanto, uma máscara para as escolhas políticas feitas por indivíduos livres, mas que servia como um veículo legitimador para nossa alienação uns dos outros, fazendo com que nossa alienação parecesse ser a personificação da justiça e obscurecendo nosso verdadeiro destino espiritual e moral como seres comunais $[\ldots]^{10}$ (Gabel,, 2009:525 tradução livre nossa).

O mesmo autor, observa Neris, apresenta um ponto fundamental: destaca que as consequências do uso da linguagem dos direitos para a mobilização social frequentemente embutem o que chamamos aqui de um campo de batalha discursivo arriscado, pois os movimentos sociais perdem energia e vivacidade com o risco de cooptação por essas forças tradicionais. Como vemos com certa regularidade desmotivante no Brasil, alguns movimentos, ainda que legítimos nas origens, terminam por contribuir para que posições contrárias a seus objetivos sejam legitimadas nesse jogo de polissemias e interesses.

Nessa conjuntura, vamos observar nosso primeiro "braço d'água": Patricia Williams e seu trabalho no escarpado entre linguagem e direito. Ainda que as correntes críticas no interior dos CLS não demandasse inteira deserção da linguagem dos direitos, sabiam os críticos e críticas que a complexidade trazida pelas manipulações e reforço estrutural trouxe justa descrença em relação ao discurso dos direitos como latência emancipatória. E que essa ideia de complexidade era alimentada pela indeterminação e efeito de alienação da linguagem. Nesse fluxo, já encontramos Patricia J. Williams, na década de 1980, com integrantes de coletivos com olhar agudo sobre situações de raça e gênero, indicando a inclinação recorrente dos CLS em silenciar temas fundamentais .

Em 1987, quando da realização da décima conferência do coletivo, cujo tema foi "Racismo e Direito", Jose Bracamonte, Richard Delgado, Mari Matsuda, Harlon Dalton e nossa citada Patricia J. Williams, apresentaram trabalhos reconhecidos até hoje como notáveis contribuições da CRT ao debate crítico norte-americano. ${ }^{11}$ Além de professora associada na Escola de Direito da Universidade de Wisconsin (no departamento de estudos de gênero) Williams ingressou como docente de direito na Universidade de Colúmbia em 1991. Em 2013, com justiça, o Center for Gender \& Sexuality Law (Centro

$10[\ldots]$ the problem with law was not that it was indeterminate and therefore a mask for political choices made by free individuals, but that it was serving as a legitimating vehicle for our alienation from one another, making our alienation appear to be the embodiment of justice and obscuring our true spiritual and moral destiny as communal beings [...] (Gabel, 2009:525).

11 NERIS, Um efeito alquímico... ob. cit. na nota 4 
para o Direito de Gênero e Sexualidade) da faculdade de Direito de Colúmbia homenageou-a com um simpósio e, em 2019, ela foi eleita membra da American Philosophical Society. Retomaremos adiante o conflito necessário da CRT e dos CLS e as análises de Williams, para debruçarmo-nos sobre nossas personagens.

Patricia Hill Collins, embora bem mais conhecida no Brasil, ainda encontra a resistência da disseminação acadêmica no sentido do reconhecimento de sua produção intelectual (Williams, infelizmente, tem a obra ainda menos lida em nosso país, inclusive por limitações de tradução). Nota Winnie Bueno ${ }^{12}$ que, conquanto existam artigos e citações sobre a obra de Patricia Collins, há poucos materiais em português que falem sobre sua obra e praticamente nada acerca de sua trajetória pessoal.

Como assinalamos na introdução, o universo pessoal não apenas é político, e a tradição da ascendência e descendência ancorada na oralidade faz especial sentido quando sabemos que as contribuições de mulheres negras seguiram por esse acidentado e silenciado curso d'água, enquanto as comportas das academias permaneciam acessíveis à branquitude. A própria Collins considera indispensável a narrativa das próprias histórias pelos sujeitos e recorda ser esta uma das características do pensamento feminista negro. Para Collins, a interseccionalidade também é lastreada no fato de que a figura da intelectual negra não está reduzida às mulheres negras inseridas no espaço acadêmico. Exige o reconhecimento de que toda forma de atuação das mulheres negras consista no seu fortalecimento como sujeito e na sua autovalorização, sendo produção intelectual fundamentada no feminismo negro.

É inegável que os espaços de educação formal por anos foram proibidos à população negra e, à medida que se tornaram permitidos, criaram-se mecanismos formais e informais de negação de acesso e impedimento de permanência. Isso resultou na produção de conhecimento como prática de resistência, forjando-o em todos os demais espaços onde as mulheres negras estivessem presentes. No dizer de Collins, tal fato se dá baseado no entendimento e na prática política de que a sombra que obscurece essa complexa e rica tradição intelectual das mulheres negras não é acidental, nem benigna. Suprimir os conhecimentos produzidos por qualquer grupo oprimido facilita o exercício do poder por parte dos grupos dominantes, pois a aparente falta de dissenso

12 BUENO, Winnie. A relevância de Patricia Hill Collins para o ativismo intelectual de mulheres negras. Justificando. 8 mar. 2018. Disponível em:https://is.gd/Jur0062 ou $<$ http://www.justificando.com/2018/03/08/a-relevancia-de-patricia-hill-collins-para-o-ativismo-intelectualde-mulheres-negras/>. Acesso em 10 jan. 2021. 
sugere que os grupos subordinados colaboram voluntariamente para sua própria vitimização. $^{13}$

Como reforça Bueno, Collins reflete as experiências das mulheres negras constantemente a partir da própria história, transmutando em teoria o subjetivo e centralizando as práticas políticas e afetivas das mulheres negras como estratégias ímpares para a retomada de vozes coletivas que historicamente são silenciadas. Observa que Collins "consegue propor alternativas e estratégias para outros grupos subordinados a partir dos processos de resistência e auto-conhecimento de mulheres negras, os quais se dão para além dos espaços institucionais". ${ }^{14}$ Collins bebeu da influência positiva de Pauli Murray, também advogada e a primeira mulher negra a ser ordenada episcopisa (bispa) pela igreja anglicana. Ainda na universidade, Patricia Collins atuou com movimentos progressistas no interior da comunidade negra de Boston. Os conceitos que a autora desenvolve em Black Feminist Thought organizam-se a partir dos históricos e trajetórias das mulheres negras afro-americanas e Hill Collins construiu sua obra utilizando conceitos de intelectuais do pensamento filosófico ocidental clássico, revelando impulsionamento ímpar para calcar a relevância do pensamento intelectual feminista negro. Ao discorrer sobre interseccionalidade Patrícia Hill Collins ressalta que as ponderações acerca da temática ganharam visibilidade a partir de outras intelectuais que traziam em seu escopo críticas à limitação das análises isoladas. Sendo 1. Gênero como questões referentes apenas aos estudos de mulheres e que interessavam ao feminismo; 2. Raça como interesse do movimento negro, majoritariamente focado nos homens negros; 3 . Classe como uma categoria de análise voltada para o campo de interesses estruturais. Tais limitações, afirma Collins, foram inicialmente demonstradas por juristas como Patrícia Williams e Kimberlé Crenshaw, destacando que não foi objetivo delas constituir uma teoria, categoria de análise ou ferramenta metodológica, evitando, assim, os riscos decorrentes em "se perder na tradução ${ }^{15}$." Analisar todos esses "passos que vem de longe" nos faz compreender que o arcabouço teórico de Williams foi rico o suficiente para permitir uma qualidade e fineza no seu olhar para os CLS e garantiu a acuidade de suas contribuições na corrente da CRT. E que sua densidade é traduzida na obra de Collins à medida que esta refere-se em muitos de seus escritos a como Williams fez seguir o curso

13 COLLINS, Patricia Hill. Pensamento feminista negro: conhecimento, consciência e a política do empoderamento. Trad. Jamile Pinheiro Dias. São Paulo: Boitempo, 2019, p. 32.

14 BUENO, A relevância de Patricia Hill Collins..., ob. cit. na nota 8.

15COLLINS, Pensamento feminista negro, ob. cit. na nota 9, p. 15. 
das águas do riacho interseccional para que se unisse às corredeiras em direção à justiça social.

Um dos pontos fundamentais que converge academicamente com Patricia Williams é a clareza de Hill Collins sobre a afirmação feminista negra. Não apenas em "O que é um nome: Mulherismo, feminismo Negro", mas em sua obra recentemente publicada em português, reforçando o valor da identificação como feministas negras:

\begin{abstract}
Recusar o termo "feminismo negro" desestabiliza o racismo inerente ao apresentar o feminismo como uma ideologia e um movimento político somente para brancos. Inserindo o adjetivo "negro" desafia a brancura presumida do feminismo e interrompe o falso universal deste termo para mulheres brancas e negras. Uma vez que muitas mulheres brancas pensam que as mulheres negras não têm consciência feminista, o termo "feminista negra" destaca as contradições subjacentes à brancura presumida do feminismo serve para lembrar às mulheres brancas que elas não são nem as únicas nem a norma "feministas". ${ }^{16}$
\end{abstract}

O pensamento feminista negro, que aqui buscamos trabalhar nas perspectivas de Collins e Williams, em especial na categorização de raça como resistência e importante dissonância aos movimentos acadêmicos críticos, constitui um projeto de conhecimento que examina a produção intelectual das mulheres negras em resposta aos desafios específicos que enfrentamos. No caso de ambas, seus olhares voltaram-se para a política dos Estados Unidos e a sociedade estadunidense, mas não perderam de vista a necessidade de enriquecer o olhar por si mesmas e sobretudo alertar o entorno sobre essa diversificação.

Em sua última vinda ao Brasil, por exemplo, Angela Davis afirmou que sentia esperança no país e que havia muitas referências de feministas negras aqui, dentre as quais citou Lélia Gonzalez, e disse não se sentir confortável ao ser reverenciada com um fervor intenso que não era direcionado à intelectual brasileira na mesma proporção. ${ }^{17} \mathrm{Em}$ entrevista, Collins referiu-se a Sueli Carneiro quando inquirida pela entrevistadora sobre ter citado a filósofa e ativista brasileira em edição mais recente da obra Pensamento feminista negro:

[...] nunca a conheci pessoalmente. Contudo, quando publiquei meu livro em 1990 - Pensamento feminista negro foi publicado originalmente neste ano -, as pessoas começaram a dizer coisas para mim. Você sabe, nós conversamos

16 COLLINS, Pensamento feminista negro, ob. cit. na nota 9, p. 39.

17 GALVANI, Giovanna. "O Brasil ainda me dá esperança”, declara Angela Davis... CartaCapital, 22 out. 2019. Disponivel em <https://is.gd/Imprensa096> ou <https://www.cartacapital.com.br/sociedade/o-brasil-ainda-me-da-esperanca-declara-angela-davis/>. Acesso em 31 jan. 2021 
sobre o nosso trabalho com outras pessoas, não é? E elas diziam "sabe, tem algumas coisas acontecendo no Brasil, feministas negras brasileiras estão levantando algumas questões." E eu gostaria de poder te dar o nome da pessoa que me enviou alguns materiais! Porque até aquele ponto o trabalho dela [Sueli Carneiro] não tinha sido publicado em inglês. E era realmente o que estava acontecendo: o Brasil não estava chegando até nós. Mas essa pessoa achou algo em inglês e enviou para mim. Eu lembro de trabalhar em uma ou duas referências e pensar: "Isso é exatamente o que estamos fazendo aqui e eu preciso saber mais!" [...] Eu sou muito grata por essa pessoa ter enviado esses artigos para mim e me dizer "você também precisa pensar globalmente sobre como está o feminismo negro dos Estados Unidos". Então, eu fui capaz de dizer e digo de forma consistente desde então que penso que o feminismo negro dos Estados Unidos é um discurso particular pertinente àquele país. O que precisamos é saber mais sobre o feminismo negro brasileiro, moçambicano, e falar entre nós sobre quais são as afinidades e diferenças. Essa foi realmente a mudança de pensamento ue eu fiz de 1990 a 2000 e encontrar o trabalho de Sueli [Carneiro] foi central para expandir o meu pensamento enquanto acadêmica e feminista. ${ }^{18}$

Winnie Bueno destaca, com razão, que, embora o patriarcado, o colonialismo, o racismo e o sexismo tenham constituído formas de dominação que caracterizaram o período de escravização e que, não obstante apresentem dinâmicas diferentes em cada contexto nacional que influenciaram a formação dos aspectos da vida social, urge ressaltar que há diferenças a serem examinadas. Patricia Hill Collins assinala que os diferentes sistemas de dominação apresentam sua própria malha de poder. E isto criará implicações distintivas em cada contexto social. Por exemplo, continua Bueno, o sistema escravocrata no Brasil e nos Estados Unidos apresentou características que, analisadas em prisma global, apresentam contornos semelhantes. Ainda assim, não é possível meramente entender esses dois contextos de forma igualitária, como se os impactos produzidos na vida social dos sujeitos localizados em cada um desses países fossem idênticos, apesar de estruturalmente semelhantes. ${ }^{19} \mathrm{Em}$ correnteza que antecede Bueno, Lélia Gonzalez já desaguava entre nós a limpidez de compreendermos a amefricanidade, a experiência de povos em diáspora nas Américas, e de como essa vivência se dava nos contextos específicos do Brasil, dos Estados Unidos, da Jamaica e demais territórios constituintes da Améfrica. A experiência das mulheres negras embora dotada de semelhanças não é a mesma. E por tais razões, devem ser consideradas as inúmeras possibilidades de diálogos contínuos entre os feminismo afroamericano e afrobrasileiro,

18 "Feminismo precisa ser cuidadoso para não perder o sentido". Entrevista de Patricia Collins para o lançamento de "Pensamento Feminista Negro" no Brasil, publicada em 27.10.2019. Por Andréa Martinelli. Disponível em: <https://www.geledes.org.br/feminismo-precisa-ser-cuidadoso-para-nao-perdersentido-diz-patricia-hill-co llins/> Acesso em 3 jan. 2021.

19 BUENO, A relevância de Patricia Hill Collins..., ob. cit. na nota 8. 
somadas a experiências semelhantes no contexto transnacional. ${ }^{20}$ Amparando-se, aliás, no que bem afirma Collins, "para mim, as mulheres negras não são nem super-heroínas destemidas capazes de conquistar o mundo, nem vítimas oprimidas que precisam ser salvas". ${ }^{21}$

Collins acrescentou "Alchemical Notes: reconstructing ideals from deconstructed rights", de Patricia Williams, à sua obra Black Feminist Thought, há pouco tempo. O livro de Collins fora lançado em 1990, com apenas um ano antes do de Williams, que é de 1991. Não fazia referência a "Alchemical Notes", artigo de 1987, o embrião que deu origem ao livro de 1991. Todavia, passou a referenciar Williams, incluindo em 1995, com o lançamento de The Rooster's Egg.

3 Williams, Critical Race Theory e as aproximações do pensamento de Collins

"Alchemical Notes: reconstructing ideals from deconstructed rights" foi publicado na coletânea Minority Critiques of the Critical Legal Studies Movement, de 1987, pela Harvard Civil Rights-Civil Liberties Law Review. Os trabalhos dessa obra de Patricia Williams foram originalmente apresentados na décima conferência dos CLS, que teve como tema "Racismo e Direito". As controvérsias e debates presentes no artigo foram incorporados, com poucas alterações, à obra The Alchemy of Race and Rights: Diary of a Law Professor, em 1991, com o título "The pain of word bondage", e publicados em espanhol pela Universidad de Los Andes de Bogotá, na obra La Crítica de los Derechos, em 2003, com o título "La dolorosa prisión del lenguaje de los derechos", como aponta Natália Neris. ${ }^{22}$

Não muito longe, em 1990, Collins lançava seu Black Feminist Thought, observando:

Comumente, feministas apontam com confiança para suas opressões sofridas por serem mulheres, mas resistem em ver o quanto de privilégio sua pele branca lhes traz. Afro-americanos que têm análises eloquentes sobre o racismo frequentemente persistem em ver mulheres brancas pobres como símbolo do poder branco. A esquerda radical não se sai muito melhor. "Se ao menos pessoas negras e mulheres pudessem ver seus verdadeiros interesses de classe", argumentam, "a solidariedade de classe poderia eliminar o racismo e o machismo". Em essência, cada grupo identifica o tipo de opressão

20 COLLINS, Pensamento feminista negro, ob. cit. na nota 9, p. 13.

21 COLLINS, Pensamento feminista negro, ob. cit. na nota 9, p. 12.

22 NERIS, Um efeito alquímico, ob. cit. na nota 4. 
que se sente mais à vontade em atribuir como fundamental e classifica todos os outros tipos como menos importantes. ${ }^{23}$

O trabalho de Collins articula diversas correntes teóricas, como estudos de gênero e etnia, classes sociais, sociologia da ciência, pensamento social marxista e teoria crítica. Com influência da Perspectiva Feminista, de Sandra Harding, e dos trabalhos de Angela Davis, que na visão da autora, compreende uma das principais referências dos estudos de gênero e etnia. E com o contributo das histórias de vida das mulheres negras que Collins colhe ao longo de sua pesquisa.

A experiência de Collins não difere dos desafios encontrados por Williams na academia. A construção de uma epistemologia que valorize o ponto de vista da mulher negra é fundamental para Collins e este é o obstáculo enfrentado por Williams nos Critical Legal Studies. Os CLS podem ser delimitados de três modos diversos: como um movimento de docentes e estudantes de direito no período de 1970 e 1990, que objetivavam a crítica de esquerda ao sistema jurídico estadunidense e a reforma do ensino jurídico; como uma escola cujos conceitos continuam a influenciar a produção teórica em diferentes campos, apesar de poucos/as representantes atuais; como uma conciliação de teorias, entre as quais o Realismo Jurídico Estadunidense, o Marxismo Frankfurtiano, o Pós-Marxismo, o Estruturalismo Francês e o Pós-estruturalismo, como compreendemos. $^{24}$

Segundo apontamos, na década de 1980 integrantes de coletivos apontaram o recorrente silenciamento dos CLS em temas de raça e gênero. Patricia J. Williams trará, em 1987, contribuições da CRT ao debate crítico. O grupo de intelectuais ligado à CRT enfrenta a dinâmica funcional da "raça" na sociedade pós-direitos civis nos Estados Unidos. Investigando progressos e retrocessos dessa fase, visa, segundo Crenshaw, a realizar intervenção crítica no discurso liberal sobre raça e intervenção racial no discurso

23 COLLINS, Pensamento feminista negro, ob. cit. na nota 9, p. 52.

24 KENNEDY, Duncan; KLARE, Karl. E. A Bibliography of Critical Legal Studies. In: The Yale Law Journal, v. 94, No. 2, Dec. 1984, p.461-490. Disponível em <http://www.duncankennedy.net/documents/Photo\%20articles/A\%20Bibliography\%20of\%20cls.pdf>. Acesso em: 31 jan. 2021. 
crítico do direito. ${ }^{25}$ Como bem examina Natália Neris, ${ }^{26}$ a CRT irá além, ao demonstrar que mesmo correntes como o "colorblindness constitucionalism" (constitucionalismo cego à $\operatorname{cor}^{27}$ ) ou visões como neutralidade, objetividade e (como esquecer?) a retórica do mérito, contribuíram e permanecem contribuindo para perpetuação, preservação e legitimação do regime de supremacia branca e subordinação das comunidades afro-americanas.

Destaca Neris que essa concepção do racismo como fenômeno sistêmico "e, portanto, presente nos discursos, práticas e instituições, fora útil tanto para intervenção crítica no discurso liberal quanto no discurso crítico do direito". Observa que autores como Villegas et al. examinam que, para a CRT

la ausencia del tema racial em las reflexiones de los CLS y el hecho de que esta ausencia no fuese interrogada criticamente, indicaban que los CLS construían y reproducían el poder racial de manera muy similar a las instituciones que pretendían criticar y desmantelar. ${ }^{28}$

Dessa forma, não apenas a heterogeneidade de temas é uma das características que a CRT apresenta. Além da discussão de conceitos como raça, racismo, essencialismo, anti-essencialismo, buscaram-se enfoques interdisciplinares em outras realidades sociais. Não por acaso, chegamos a um ponto de inflexão reforçado por Collins: se a experiência das mulheres negras estadunidenses, no que se refere ao tipo de trabalho a que estão sujeitas, ao tipo de comunidade em que vivem e ao tipo de relacionamento que mantêm com o outro tornaria diferente a vivência dessas mulheres. Mais uma razão pela qual Collins em Pensamento feminista negro, afirma "os temas principais que norteiam o livro - trabalho, família, política sexual, universo da mulher e ativismo político - se interrelacionam e são moldados por um sistema de opressão que ela denomina matriz da dominação"..$^{29}$

25 CRENSHAW, Kimberlé Williams. The first decade: critical reflections of "a foot in the closing door." In: UCLA Law Review, v. 49, No. 5, Jun. 2002. Disponivel em: <https://is.gd/Jur0063> ou $<$ http://www2.law.columbia.edu/fagan/courses/law socialscience/documents/Spring 2006/Class\%202Ori gins\%20of\%20Social\%20Science\%20Law/Crenshaw_Foot\%20in\%20the\%20Closing\%20Door.pdf>. Acesso em: 31 jan. 2021.

26 NERIS, Um efeito alquímico, ob. cit. na nota 4.

27 Também conhecido como "discurso dos direitos civis", o "constitucionalismo cego à cor" surge no discurso jurídico americano a partir da decisão do caso Brown vs. Board Education, de 1954, que proibiu a segregação racial em escolas.

28 VILLEGAS, Mauricio Garcia; SIERRA, Isabel Cristina Jaramillo e SALDARRIAGA, Esteban Restrepo. Crítica Jurídica: Teoria y Sociologia Juridica en los Estados Unidos. Bogotá: Universidad de los Andes, Faculdad de Derecho, 2005, p. 33.

29 COLLINS, Pensamento feminista negro, ob. cit. na nota 9, p. 240. 
Collins avança enxergando à frente a dominação exercida por homens brancos que têm controle não só social, mas também econômico, da informação e do conhecimento. Não por acaso, ela vê como trincheira da consolidação do pensamento feminista negro alguns caminhos. A validação do Pensamento Feminista Negro passa pelo exame de três divergentes grupos: da mulher negra comum (pois Collins compreende que o conhecimento é fortemente baseado na sua vivência e experiência), das intelectuais negras e, por fim, do grupo dominante, que controla escolas, programas acadêmicos, publicações e variados mecanismos de legitimação do conhecimento que permanecem até hoje. ${ }^{30}$ Lembremos que Collins obteve seu mestrado em Harvard, em 1970, e Williams seu doutorado na mesma universidade, em 1975.

Collins vai ao encontro de determinadas reflexões da CRT na defesa das subjetividades: aposta nas mulheres negras como agentes do conhecimento, pois elas seriam as pessoas autorizadas a discutir um conhecimento teórico baseado em suas próprias experiências. Para isso, é preciso resistir à teoria hegemônica e encontrar espaços e caminhos para o Pensamento Feminista Negro. Na CRT se observa que, à parte a crítica ao uso da retórica do direito, para Delgado (1988) e outros intelectuais como Matsuda (1992) e Crenshaw (1995), o "lugar de fala" de grande parte dos acadêmicos dos CLS informa e determina seus posicionamentos. Considerando esse aspecto, os críticos raciais têm postulado que, além da intervenção crítica no discurso liberal e no discurso crítico do direito, é fundamental construir um conhecimento pautado na percepção de setores sociais marginalizados, a fim de que dinâmicas de subordinação sejam alteradas. ${ }^{31}$

Nesse cenário insere-se Patricia Williams, alimentando a inquietação necessária em relação a alguns dos teóricos dos CLS que propõem abandono do discurso ou linguagem dos direitos. Com histórias reais e subjetividades expostas, inclusive pela própria Williams, com a pungente análise do caso de seu tataravô, homem adulto que abusa de sua tataravó criança escravizada, Williams provoca raciocínios divergentes por meio da proposta: "o que necessitamos não é abandonar a linguagem dos direitos para todos os propósitos, mas intentar sermos multilíngues na semântica para avaliá-los". 32

30 Recordamos o comentário da própria autora já citado aqui sobre os obstáculos que só permitiram a tradução de sua principal obra para o português trinta anos depois.

31 NERIS, Natália. Um efeito alquímico: sobre o uso do discurso dos direitos pelas/os negras/os. Revista Direito e Práxis. Vol. 9, n. 1, Rio de Janeiro; Jan./mar. 2018. Disponível em <https://is.gd/Jur0061> ou <https://doi.org/10.1590/2179-8966/2017/25487>. Acesso em 12 jan. 2021.

32 WILLIAMS, Patricia J. Alchemical Notes: Reconstructing Ideals from Deconstructed Rights. In: Harvard Civil Rights - Liberties Law Review. V. 22, No. 2, Spring 1987. p. 24 e 24. 
Patricia Williams mostra que as "necessidades" da esquerda branca são circunstanciais. ${ }^{33} \mathrm{O}$ discurso dos direitos pode parecer uma espécie de "prisão semântica" para quem está no ponto privilegiado da balança. Quem já dispõe de forma usual de direitos pode achar natural querer abrir mão deles porque os sapatos não Ihe caberiam com perfeição. Porque Ihes incomoda a polissemia. As necessidades das pessoas negras são de outra ordem. Padrões de desapropriação física e psíquica, habilmente engendrados e penosos no período da escravidão e a vigência do racismo na contemporaneidade fazem o discurso dos direitos para muitas pessoas negras ganhar força. Como diz Williams, para quem sempre foi colocado historicamente em posição impotente, "a concessão de direitos é símbolo de todos os aspectos de sua humanidade que têm sido negados: os direitos implicam um respeito que os localiza em uma categoria referencial de 'eu' e 'outros', que eleva seu status de corpo humano ao de ser social". ${ }^{34}$

Do outro lado, a epistemologia feminista negra, pensada por Patricia Hill Collins, recrimina argumentos de competição entre os mais excluídos, as hierarquias entre eixos de opressão e violações consideradas menos recorrentes. De forma conjunta, racismo, capitalismo e heteropatriarcado precisam ser encarados pela interseccionalidade observando os contornos identitários da luta antirracista diaspórica.

Collins sublinha, em suas conferências, não entender que o feminismo negro seja resposta ou desdobramento do feminismo branco, o chamado "hegemônico". O pensamento feminista negro, segundo Patricia Hill Collins, surge da experiência de sobrevivência de mulheres ao longo da história da humanidade. A proposta afina-se com a crítica de Williams sobre a afirmação equivocada dos CLS de que os direitos seriam inúteis para o progresso político, de que é preferencial estabelecer relações informais ou até mesmo que é preciso substituir as demandas por "direitos" por demandas que foquem "necessidades". Como esclarece, não faz sentido para pessoas negras, pois estas têm sua vulnerabilidade protegida e têm possibilidade de fugir de estereótipos por meio da utilização da linguagem dos direitos. Williams acentua que a crença no discurso dos direitos pelos negros e negras não poderia ser compreendida como reificação de conceitos ou tentativas de compensação e reafirma que, embora seja verdade que "nós, negros, nunca cremos completamente nos direitos", também era verdade que

33 NERIS, Natália. Um efeito alquímico: sobre o uso do discurso dos direitos pelas/os negras/os. Revista Direito e Práxis. Vol. 9, n. 1, Rio de Janeiro; Jan./mar. 2018. Disponível em <https://is.gd/Jur0061> ou <https://doi.org/10.1590/2179-8966/2017/25487>. Acesso em 12 jan. 2021.

34 WILLIAMS, Alchemical Notes, ob. cit. na nota 26, p. 416. 
cremos neles tanto e tão fortemente que criamos vida onde não havia, nos "agarramos" a eles, colocamos esperança neles em nossos ventres, e fomos suas mães, e não mães de conceitos. Esse processo não foi um seco processo de reificação; naquela vida se exprime e a realidade se desvanece à medida que o determinismo conceitual se endurece ao redor, se não seu oposto. Foi a ressurreição da vida entre cinzas de quatrocentos anos. Criar algo do nada exigiu muito fogo alquímico - a fusão de toda uma nação e os "gravetos" de várias gerações. ${ }^{35}$

Williams reafirma não ser necessário abandonar a linguagem dos direitos para todos os propósitos, mas intentar sermos multilíngues na semântica para avaliá-los. Isso implica ampliação de definições, significantes e possibilidades. Williams não se abate e propõe que a tarefa dos CLS corresponderia a não abrir mão destes, mas enxergar além do discurso dos direitos e fazê-los refletir uma definição mais ampla, recorrendo à figura da máscara como objeto de poder: os CLS têm desmascarado a mitologia dos direitos na América Liberal, e este é apenas o início dessa jornada. Como na mitologia, o novo xamã precisa ir além de tomar a máscara: precisa dar-Ihe uso transcendente e renovador.

A tomada dessa máscara não é fácil. O próprio ambiente acadêmico é retalhado de desafios, cuidadosamente expostos tanto por Patricia Collins, como por Patricia Williams com clara afinidade de pensamento: a de serem "outsiders" cujas posições é melhor demonstrada nas narrativas. Para Winnie Bueno, ao expor sua experiência como a única mulher negra ou como uma das poucas mulheres negras nos espaços educacionais e de trabalho e com isso causar desconforto, Patricia Collins desafia a pensar a quem serve essa espécie de representatividade que se baseia na consolidação de uma única voz como representação da multiplicidade de mulheres negras. Collins nota que "enquanto o pensamento negro pode ser registrado por qualquer pessoa, ele é produzido pelas mulheres negras" ${ }^{\prime 36}$, porém alerta que as imposições acadêmicas podem desencadear em um contexto que empurram essas mulheres à sua marginalização nas arenas acadêmica e social, mantendo-as sob o "status de outsider within". A partir dessa compreensão, Collins leva-nos a contemplar como ser a única mulher negra tem um significado que não está adstrito ao mérito e à reverberação de conquistas individuais, mas se prende a algo mais complexo, que apaga e manipula o conjunto de mulheres negras. Aponta Bueno: "se eu sou a única mulher negra a figurar em um espaço absolutamente branco, isso não

35 Idem, p. 431.

36 COLLINS, Patricia Hill. Aprendendo com a outsider within. Revista Sociedade e Estado - Volume 31 Número 1 Janeiro/Abril 2016. Acesso em: dezembro de 2019 
significa que eu esteja ocupando esse espaço por representar a comunidade negra". E segue: "talvez o esteja ocupando para atender a uma necessidade das novas dinâmicas do racismo, as quais mercantilizam o próprio ativismo de mulheres negras se estas não estão atentas às armadilhas que uma representatividade monolítica apresenta". ${ }^{37}$

É esta sensação que percebemos nas cogitações de Patricia Williams, um dos pontos fundamentais de nosso trabalho. Enquanto tantos e tantas utilizaram o pensamento interseccional como rótulo, categoria ou como instrumento sem de fato contemplarem na amplitude as intersecções de fato, ambas fizeram da interseccionalidade seu instrumento de forma pioneira no Direito e nas Ciências Sociais.

Ambas leram a realidade com a sofisticação de um olhar cuja liquidez pingava sobre as camadas trabalhosamente desfolhadas, deixando desvelar como pétalas transparentes o que o cerne enfim escondia. "Outsiders", investigativas, desbravadoras e atentas, trocaram e se tocaram em conceitos sem perderem suas peculiaridades. Como Collins, Williams também relata o olhar forasteiro. Quando estudou em Harvard, sua presença e sua contribuição- assim como a de alunas e alunos negros que entraram na instituição em virtude de ações afirmativas- eram rebaixadas. Esse cenário a induziu a absorver o conhecimento e os valores que escravizaram seus antepassados. Meditou que o poder excessivo coincide amplamente com o que se vê como exitoso ou desejável de nossa sociedade. E também Ihe trouxe a visão de que imagens de poder cederiam lugar a imagens de impotência. Ao mesmo tempo, no entanto, em nossas pesquisas percebemos o caminho encontrado: não se enquadrando no ambiente, busca um olhar crítico que pondera as discrepâncias reais das convenções sociais, determinando seu próprio caminho de vida, através de suas crenças e valores ancestrais.

4 Interseccionalidades, heranças e nós: o que chega deste rio?

A marca do termo "interseccionalidade" é atribuída a Kimberlé Crenshaw, como mencionamos, mas é inegável que a perspectiva interseccional sempre foi matriz importante da produção de Patricia Hill Collins. Considerada um dos nomes mais importantes no debate sobre "epistemologias situadas", Collins analisa que parte

37 BUENO, A relevância de Patricia Hill Collins..., ob. cit. na nota 8. 
significativa do que se considera conhecimento neutro e universal corresponde à visão de um grupo específico. Esse grupo, por compor os espaços de poder, lança e solidifica concepções tidas como válidas para todos e todas. Pensando a condição da mulher negra e discutindo como as opressões de raça, classe, gênero e sexualidade se inter-relacionam, Patricia Collins nota os sistemas de poder em manifestações simultâneas. Quando aborda a construção da identidade da mulher negra, busca não apenas romper estereótipos, mas analisa a forma como são criados e para que servem. Não deixa de acrescentar a forma com que são incorporados pelas mulheres e suas consequências. Das maiores contribuições para nossa realidade é o fato de sua obra mostrar que toda ciência tem gênero e raça, pois o lugar de enunciação sobre o conhecimento repercute no conteúdo e ressalta a invisibilização e o silenciamento de grupos marginalizados.

Carla Akotirene em $O$ que é interseccionalidade, registra: "movida por escrevivências, como Conceição Evaristo, proponho cantiga decolonial por razões psíquicas, intelectuais, espirituais, em nome d'águas atlânticas". Essa visão continua em uma irmandade que se soma à experiência de Patricia Hill Collins e de Patricia Williams, corpos estranhos à universidade colocados sob a condição de outsider within, aquelas a quem Mannheim apud Collins ${ }^{38}$ denomina de "estrangeiros na academia" tratados como intelectuais marginais. A afirmação de Mannheim citada por Collins ressalta que "a postura crítica que esses indivíduos trazem aos empreendimentos acadêmicos pode ser essencial para o desenvolvimento criativo das próprias disciplinas acadêmicas" 39 . Necessário, entretanto, lembrar que Patrícia Hill Collins afirma que a interseccionalidade não se resume a um conceito acadêmico tampouco a uma ferramenta analítica, e que "o foco dado deve ser em razão do que a interseccionalidade faz e não o que a interseccionalidade é." ${ }^{40}$ No dizer de Collins “a própria interseccionalidade é multifacetada e como visa a entender e analisar a complexidade do mundo, requer estratégias complexas." $^{\prime 11}$

A epistemologia feminista negra pensada por Patricia Hill Collins reforça essa união necessária que se reconhece em uma estranheza indevida e encontra desafios para

38 COLLINS, Patricia Hill. Aprendendo com a outsider within. Revista Sociedade e Estado - Volume 31 Número 1 Janeiro/Abril 2016. Acesso em: dezembro de 2019.

39 COLLINS, 2016, pág. 100.

40 BILGE, Sirma e COLLINS, Patrícia Hill. Interseccionalidade. Tradução Rane Souza. São Paulo: Boitempo, 2021.

41 BILGE, 2021, pág. 48 
reafirmar o - para nós evidente - valor na construção de uma epistemologia secundarizada não pela falta de profundidade ou qualidade das águas, mas porque a intelectual negra presente nesse "não lugar" significa sua ausência nos lugares de sempre... o que sustenta sem reconhecimento quem permanece nos lugares a que estão acostumados.

Hill Collins recrimina argumentos de competição entre os/as mais excluídos/as, hierarquias entre eixos de opressão e violações consideradas menos preponderantes, desse modo, afirma que

\begin{abstract}
interseções de raça e gênero podem apontar para a necessidade de uma análise de classes ou interseções de nação e sexualidade podem indicar a necessidade de outras categorias de análise. Tal complexidade não facilita a vida de ninguém, ela complica o trabalho e pode ser uma fonte de frustração para acadêmicos, profissionais e ativistas de ambos os sexos. No entanto, a complexidade não é consequência do uso da interseccionalidade como ferramenta analítica, mas algo que aprofunda a análise interseccional. ${ }^{42}$
\end{abstract}

Collins enuncia uma outra necessidade no tocante a interseccionalidade que é a sua adoção crítica, e sentencia que "o que faz com que um projeto seja interseccional crítico é sua conexão com a justiça social." ${ }^{\prime 3}$ Uma observação imprescindível para entender que "ao negligenciarem a justiça social e princípios éticos semelhantes, estudos interseccionais que parecem mais dedicados a descrever a verdade do que criticá-la e reescrevê-la deterioram inadvertidamente o propósito da interseccionalidade em si." ${ }^{44}$ Importante frisar que o feminismo negro traz em seu horizonte promessa inicial de promover política emancipatórias para as pessoas cujos anseios eram integrar uma sociedade justa ${ }^{45}$ e a ligação com a interseccionalidade se constituía exatamente por essa proposta. A preponderância de descrições da realidade que tem feito uso frequente da interseccionalidade para tratar de questões imprescindíveis aos tempos em que vivemos, leva-nos a reproduzir aqui duas perguntas de Collins: 1."o que se perde quando os projetos interseccionais contemporâneos de conhecimento falham em incorporar um ethos de justiça social? 2. Mais importante, o que se pode obter se nos esforçarmos para desenvolver projetos interseccionais de conhecimento mais robustos, que tenham a

42 BILGE, 2021, pág. 48.

43 Idem.

44 COLLINS, Patricia Hill. Se perdeu na tradução: feminismo negro, interseccionalidade e política emancipatória. PARÁGRAFO. JAN/JUN. 2017 V.5, N.1 (2017) - ISSN: 2317-4919. Acesso em: dezembro de 2019. 45 COLLINS, 2017, pág. 15. 
justiça social em seu cerne?"46 Se direcionarmos essas duas perguntas aos Estudos Jurídicos Críticos e à Teoria Racial Crítica, por exemplo, o que poderíamos vislumbrar como pontos de vista para uma resposta satisfatória aos sujeitos alvo da proposta interseccional, a exemplo de mulheres negras e suas demandas?

É imprescindível lembrar que mulheres negras precisavam de uma resposta metodológica que abarcasse múltiplos sistemas de opressão em uma proposta teórica engajada. Akotirene faz coro à fala de Collins, salvaguardadas, por óbvio, suas construções e contribuições independentes, em breve texto opinativo ao enunciar: "má-fé pósmoderna, até poderia afirmar, entendendo os deslocamentos epistêmicos da política de tradução, certamente no bojo geopolítico dos conceitos do Norte, vêm subjacentes o repertório afrocêntrico da interseccionalidade, dos anos 2001 para cá." ${ }^{47}$

Essa reflexão da escritora baiana afina-se com a de Patrícia Hill Collins, citada por ela mesma em $O$ que é interseccionalidade, quando recorda o diagnóstico da estadunidense de que a interseccionalidade sofreria críticas por causa da política de tradução. Apesar de Hill Collins filiar-se à interseccionalidade desde a década de 1990 e ser conteudista do termo, ela acredita que a interseccionalidade criada por Kimberlé Crenshaw tem história maior do que o tamanho do individualismo sobre a quem se destina o mérito de cunhá-lo. Hill Collins está consciente dessas limitações enquanto observa os ganhos do caminho teórico:

Raça, classe e gênero ainda constituem formas de opressão que se interseccionam, mas as maneiras pelas quais elas se organizam hoje para produzir injustiças sociais diferem daquelas de épocas anteriores. Assim como teorias, epistemologias e fatos produzidos por qualquer grupo de indivíduos representam os pontos de vista e os interesses de seus criadores, a própria definição de quem tem legitimidade para realizar trabalho intelectual não só está sendo politicamente contestada como tem mudado. Recuperar tradições intelectuais feministas negras implica muito mais que desenvolver análises feministas negras com base em critérios epistemológicos convencionais. Implica também desafiar os próprios termos do discurso intelectual. ${ }^{48}$

Patricia Hill Collins contribui para a consolidação do Pensamento Feminista Negro propondo teoria centrada na teoria crítica, na qual se privilegia o ponto de vista das

46 Idem.

47 AKOTIRENE, Carla. Ferramenta anticolonial poderosa: os 30 anos de interseccionalidade. CartaCapital, 18 set. 2019.Disponivel em: <https://is.gd/Imprensa097> ou $<$ https://www.cartacapital.com.br/opiniao/ferramenta-anticolonial-poderosa-os-30-anos-de-interseccionali dade/>. Acesso em: 22 jan. 2021.

48 COLLINS, Pensamento feminista negro, ob. cit. na nota 9, p. 53 
mulheres negras na obra de 1990, recentemente traduzida para o português. Trata-se de trabalho necessário para construção de uma sociedade plural e polifônica, cujas diversas vozes podem e devem ser acomodadas no mundo do conhecimento. Collins desloca o olhar para a vivência e a interseccionalidade, consciente de que o instrumento da interseccionalidade nem sempre dará conta do combate constante às multifacetadas opressões, podendo até, em algumas situações, sofrer tentativas de apoderamento por discursos supostamente aliados. E Williams faz percurso diverso, mas que alimenta o mesmo estuário para a liberdade: não é necessário abandonar a linguagem dos direitos para todos os propósitos, mas intentar sermos multilíngues na semântica para avaliá-los.

Buscando amplificar a definição de determinados conceitos deste campo, Williams foi além quando propôs que a tarefa dos CLS é enxergar através ou além do discurso dos direitos para fazê-los pensar uma definição mais ampla de intimidade e propriedade: "[...] deixe de ser uma maneira de excluir baseada em interesse próprio e se converta em uma maneira de se ter consideração pela autonomia frágil e misteriosa do outro, e para que a propriedade recupere sua antiga conotação de ser reflexo do ser universal" ${ }^{49}$

Quais são, mais particularmente, as contribuições de Collins e de Williams para a realidade brasileira? Sem pretensões exaurientes, diante da complexidade da obra de ambas e já mencionado o olhar de "outsiders" e o instrumento interseccional manejado por ambas no capítulo anterior, fincamo-nos em dois outros pontos importantes: a percepção por Collins de que mulheres negras não são nem super-heroínas destemidas capazes de conquistar o mundo, nem vítimas oprimidas que precisem ser salvas; e da importância das análises quando da escolha teórica por determinadas temáticas.

Como a disputa de narrativas é condição comum nos espaços de produção de conhecimento e as consequências da herança colonial perduram nas Américas, é necessário alertar para os riscos de distorção a que determinadas questões políticoteórico-culturais podem estar expostas. O alerta da autora estadunidense prossegue pertinente e demonstra realizar-se por intelectuais como Lélia Gonzalez, Sueli Carneiro e Jurema Werneck, em sua postura de escrever seus próprios caminhos intelectuais: divergindo, acrescentando, criando seus prismas e entendimentos. Aponta Hill Collins:

O feminismo afro-brasileiro é fundamental para esses diálogos. As conexões cada vez mais visíveis entre o feminismo afro-brasileiro e o pensamento feminista negro dos Estados Unidos ilustram os possíveis benefícios de um

49 WILLIAMS, Alchemical Notes, ob. cit. na nota 26, p. 432. 
feminismo negro transnacional. Ambos os grupos enfrentam desafios semelhantes: por exemplo, lidar com os legados da escravidão que costumam desvalorizar a condição da mulher negra, bem como elaborar respostas ao racismo antinegro que assume formas específicas conforme o gênero. No entanto, não se pode nem se deve pensar que essas histórias e os feminismos negros produzidos por elas, ainda que semelhantes, sejam um só. As formas que esse racismo assumiu nessas duas sociedades de colonizadores brancos se mostraram extremamente variadas, assim como as relações das mulheres negras com elas. Há imenso potencial para diálogos continuos entre o feminismo afro-brasileiro e o afro-americano, o que indica possibilidades ainda mais amplas de diálogos semelhantes em um contexto transnacional. ${ }^{50}$

Patricia Hill Collins ressalta como uma das contribuições do feminismo negro o reconhecimento, pelos sujeitos, de suas próprias histórias e os pontos de diálogo com as experiências de outros indivíduos, em vez de sua incorporação acrítica. Williams acrescenta a urgente crítica de que o discurso sobre direitos em setores propaladamente críticos, conquanto busquem opor-se ao sistema, resvalam em leitura rasa do aspecto "raça" em suas reflexões. A ausência do tema racial nos raciocínios críticos ao direito repete-se no feminismo. Essa ausência não foi sequer questionada de forma contundente, mesmo que, por exemplo, como aponta Akotirene, Sojourner Truth, pensadora não alfabetizada, pioneira do feminismo negro, tenha feito leitura interseccional, em 1851, na Convenção dos Direitos da Mulher, em Ohio, onde provocou: "Eu não sou uma mulher?"51 Essa ausência diz sem palavras que diversos movimentos críticos e o próprio feminismo constroem e reproduzem o poder racial de maneira similar às instâncias que supostamente desejavam implodir.

No Brasil, o período de 1889 a 1937 caracteriza-se pelo surgimento das associações das "pessoas de cor", que objetivavam mobilizar e conscientizar a população negra, procurando mostrar-Ihe seu valor e seus direitos.

Décadas depois, já a partir da redemocratização, os movimentos negros - em especial os coletivos de mulheres - garantiram aprovação de dispositivos na Constituição de 1988 . Coletivos e grupos que já enfrentavam com coragem os temas de gênero nos próprios coletivos. A articulação e organização política de mulheres negras era visível em propostas que uniam redemocratização e combate ao racismo e ao sexismo já nas décadas de 1970 e 1980. E é evidente o impacto do engajamento dessas mulheres no período pré-constituinte e posteriormente, na construção de uma agenda

50 COLLINS, Pensamento feminista negro, ob. cit. na nota 9, p. 13.

51 AKOTIRENE, Ferramenta anticolonial poderosa, ob. cit. na nota 33. 
interseccional na própria Assembleia Nacional Constituinte. Isso reforça a crítica levantada também por Patricia Williams das camadas que já mencionamos: de um lado, as mulheres negras denunciam ausência de compromisso com o combate ao racismo por parte da esquerda e do feminismo liberal. De outro, encontram sexismo no próprio movimento negro. Remete ao duplo desafio que citamos: o que enfrentam mulheres negras dotadas de saberes, reconhecidos academicamente ou não.

Como percebida por Williams, a segunda camada é visível: para além do feminismo branco, perceberam também as brasileiras como as mulheres negras desempenhavam papéis secundários nas associações coletivas negras, bem como na imprensa negra, atuando como auxiliares nas ações de homens negros no protagonismo.

A criação da Reunião de Mulheres Negras Aqualtune (REMUNEA) em 1978, o Grupo Luiza Mahin de 1980, com Lélia Gonzalez e Zezé Motta; o Nzinga - Coletivo de Mulheres Negras, também fundado com a ajuda de Gonzalez, e o Coletivo de Mulheres Negras (SP), criados em 1983, são partes fundamentais desse processo de desvelamento da camada. Além disso, elas agiram politicamente nas fontes de criação e pressão na Assembleia Nacional Constituinte (ANC) de 1987-1988, mesmo com apenas onze representantes negros eleitos na época e 26 deputadas mulheres - nenhuma senadora. A atuação das feministas negras nos coletivos que participaram das reuniões e audiências públicas que antecederam a ANC significou forte impulso para a luta por inclusão no texto constitucional de demandas indispensáveis dos recortes de classe, raça e gênero ${ }^{52}$, levando a interseccionalidade além.

Não é compreensível que somente em 1995 a Revista Estudos Feministas, principal publicação na temática, tenha apresentado um dossiê sobre mulheres negras, composto com artigos das principais ativistas negras do país. Ora, é fato que as narrativas vão além das portas (frequentemente cerradas) acadêmicas. Faltavam (e faltam) mulheres negras na academia, todavia não faltam mulheres negras produzindo conhecimento. Assim, imaginar que a lacuna anterior existente de trabalhos acadêmicos com perspectivas interseccionais nas revistas fosse relacionada à falta de mulheres negras na academia brasileira para produzir seria servir justamente ao discurso opressor que combatem, posto que não apenas na academia estavam as pensadoras negras que

52 PONTES, Ana. Fontes do direito e o processo histórico de silenciamento das mulheres: reinvenção do direito e não subalternização. In: FERRAZ, Carolina Valença (coord.). Manual jurídico feminista. São Paulo: Casa do Direito (Letramento), 2019. p. 117-170. 
poderiam ter sido vistas.

Ignorando (propositalmente?) os notórios constrangimentos de classe, raça e gênero, a "tradição patrilinear" da academia brasileira, como aponta Azeredo, ${ }^{53}$ dificulta pensamentos divergentes, também denunciado por Williams e Collins.

A esse padrão, Patricia Hill Collins relaciona os efeitos do pós-modernismo, sobretudo no ensino superior, que tem promovido "um lugar em que a inclusão simbólica com frequência toma o lugar de mudanças substanciais genuínas" ${ }^{54}$. A forma de supressão que utiliza diversidade como estratagema para não inserir de forma substancial as mulheres negras nas ações e estudos propostos podemos classificar como tokenismo..$^{55}$ Mulheres negras são escolhidas a dedo no sentido de validar as ações utilitaristas e escamotear o caráter racista que as compõem. Essa caracterização se dá tanto do ponto de vista da presença performática dessas mulheres em atividades pontuais quanto na abordagem superficial de temas prioritários para as mulheres negras. Também no uso generalizado do pensamento de uma intelectual negra, por exemplo, como se fosse a única a produzir conhecimento e com capacidade para tratar de dimensões pertinentes à população negra ou capaz de tratar de assuntos exclusivamente relacionados a pessoas negras, figurando como (re)produtora de um conhecimento segmentado e setorizado.

Nesse cenário, Carneiro e Santos ${ }^{56}$ já elaboravam, em 1985, consonante às protagonistas deste artigo, ponderações segundo as quais para as mulheres negras cabe dupla militância, dentro e fora dos movimentos, usando a interseccionalidade como instrumento. Militância que visualiza a interseção de raça, gênero e classe como forma específica de opressão deve ser considerada na totalidade, e sua atuação nos movimentos negro e feminista objetiva "[...] sensibilizá-los para o combate ao sexismo e ao racismo como elementos estruturantes na definição de um projeto de uma sociedade justa e igualitária" ${ }^{57}$

53 AZERÊDO, Sandra. Teorizando sobre gênero e relações raciais. Revista Estudos Feministas. Ano 2, 2. sem. 1994, N. Especial. p. 203-6.

54 COLLINS, Pensamento feminista negro, ob. cit. na nota 9, p. 38.

55 Ato de usar certa imagem ou discurso como token e, assim, causar a impressão de que aborda o padrão de inclusão de determinados sujeitos políticos, mas o que ocorre é somente uso funcional de imagens, nomenclaturas, citações e qualquer forma de objetificação possível no tocante a discussões sobre inclusão e promoção da igualdade.

56 CARNEIRO, Sueli; SANTOS, Tereza. Mulher negra. São Paulo: Nobel/Conselho Estadual da Condição Feminina, 1985.

57 RIBEIRO, Matilde. Mulheres negras brasileiras: de Bertioga a Beijing. Revista Estudos Feministas. Ano 3, 2. 
Defendemos que as obras de Patricia Hill Collins e de Patrícia J. Williams, embora inseridas em debate teórico nos estudos críticos do direito nos Estados Unidos, geram contribuição ao campo feminista e jurídico que não se limitam a esses contextos. Os pressupostos da CRT e as ideias de Williams revelam ceticismo com a posição defendida pelo CLS, que argumenta ser a positivação de direitos insatisfatória e, portanto, pouco útil. Não se pode cair na armadilha de invisibilizar os profundos esforços empreendidos para essa positivação pelas muitas que vieram antes de nós e garantiram o direito a uma sociedade pouco menos desigual. Tampouco é caso para deslumbre, mas de não perder de vista o horizonte em que todas nós, mulheres, precisamos compreender a dinâmica da raça em nossa sociedade e assimilar ainda mais a noção da arena em que se torna o direito como espaço de peleja e disputa de sentido.

Essas discussões no Brasil lembram atualmente como um dia estiveram as realizadas na era estadunidense pós-direitos civis. A despeito dos esforços sólidos dos coletivos de mulheres pré-constituintes, o avanço foi inferior aos diversos sacrifícios das militantes brasileiras. Tanto Collins como Williams convergem em muitas coisas, mas sobretudo, na instrumentalidade real da interseccionalidade, na riqueza de percepção como "outsiders" e, deste lugar, ainda que não lhe tenham permitido correr seus regatos, usaram seus sentidos e mentes em chuva miúda que, ao não lavarem as mãos dentro da crítica, minando e pingando insistentemente na pedra do racismo a ponto de construírem deste lugar de distanciamento involuntário, um olhar privilegiado. Cresceram seus reflexos cristalinos na compreensão de que é possível desenhar andanças teóricas por meio da subjetividade de histórias de vida, na narrativas e storytelling, destemidas sobre desvelar a si mesmas para então desvelar o mundo.

\section{Considerações Finais}

A interseccionalidade precisa manter-se atenta a cooperar como instrumento discursivo e metodológico capaz de trabalhar pelo acesso a direitos de forma integrada e autônoma do projeto colonialista. Reconhecer que raça, gênero e classe são categorias políticas indissociáveis de análise poderá apontar caminhos na superação das desigualdades. Sueli Carneiro recorda que os efeitos do racismo e do sexismo são tão brutais que acabam por impulsionar reações capazes de recobrir todas as perdas já postas 
na relação de dominação. A emergência de articulações de mulheres negras vem desenhando novos cenários e perspectivas para as mulheres como um todo, reforçando o que sabemos: quando as mulheres negras se movimentam, toda a estrutura da sociedade se movimenta com ela (Angela Davis).

Se a ideia de interseccionalidade se refere a formas particulares de opressão, por exemplo, intersecções entre raça e gênero ou entre sexualidade e nação, os paradigmas interseccionais lembram que a opressão não é redutível a um tipo fundamental. As formas de opressão agem em conjunto na produção de injustiça. Independentemente de intersecções específicas, os domínios de poder estruturais, disciplinares, hegemônicos e interpessoais reaparecem em formas muito diferentes de opressão, como lembra Collins.

Compreender a interseccionalidade de raça, gênero e classe no exercício da matriz de dominação implica também compreender a necessidade de pensar, planejar e executar ações articuladas que permitam a superação das desigualdades baseadas nessas dimensões e viabilize promoção de justiça social. A teorização a partir da experiência pessoal, defendida por Williams e por Collins é, a nosso ver, um dos principais pontos de conexão entre ambas, porque as vozes das mulheres negras importam sobremaneira para identificar as desigualdades, e isto é fundamental para planejamento, execução e avaliação dos instrumentos. A disseminação e fortalecimento da produção acadêmica de teóricas negras é urgente, pois como categoria produtora de novas epistemologias, o feminismo negro aponta caminhos e direcionamentos para compreender o mundo a partir de uma visão para além de não hegemônica: o protagonismo intelectual das mulheres negras viabiliza entendimento especial da matriz de dominação e, consequentemente, a esperança de sua superação.

Lavando a limpo e lavando a alma das mulheres, ambas autoras generosamente alimentaram seus cursos d'água iniciais, aumentaram os seus através das águas de outras mulheres e trouxeram novos pontos que permitem hoje lavar os olhos de todas e todos que queiram enxergar. Transformando-se em minas próprias, poderão fazer brotar flores que se transmutarão nos frutos para alimentar as novas gerações. Que suas obras possam continuar e ampliar produções acadêmicas empenhadas em transformações reais e na superação de sistemas que se afastam dos direitos das mulheres no Brasil e no mundo...é nosso desejo.

\section{Referências Bibliográficas}


AKOTIRENE, Carla. Ferramenta anticolonial poderosa: os $\mathbf{3 0}$ anos de interseccionalidade. CartaCapital, 18 set. 2019. Disponível: <https://is.gd/Imprensa097>ou $<$ https://www.cartacapital.com.br/opiniao/ferramenta-anticolonial-poderosa-os-30anos-de- interseccionalidade/>. Acesso em: 22 jan. 2021.

AKOTIRENE, Carla. Interseccionalidade. São Paulo: Sueli Carneiro / Pólen, 2019.

AZERÊDO, Sandra. Teorizando sobre gênero e relações raciais. Revista Estudos Feministas. Ano 2, 2. sem. 1994, N. Especial. p. 203-6.

BILGE, Sirma e COLLINS, Patrícia Hill. Interseccionalidade. Tradução Rane Souza. São Paulo: Boitempo, 2021

BUENO, Winnie. A relevância de Patricia Hill Collins para o ativismo intelectual de mulheres negras.Justificando. 8 mar. 2018.2 Disponível em:<https://is.gd/Jur0062> ou<http://www.justificando.com/2018/03/08/a-relevanciade-patricia-hill-collins-para-o-ativis mo-intelectual-de-mulheres-negras/>. Acesso em 10 jan. 2021.

BUENO, Winnie. Uma introdução ao pensamento de Patricia Hill Collins a partir da perspectiva de uma mulher negra do sul-sul. Alma preta. 15 jul. 2019. Disponível em <https://is.gd/Jur0064>ou<https://www.almapreta.com/editorias/o-quilombo/umaintroducao-ao-pensamento-de-pat ricia-hill-collins-a-partir-da-perspectiva-de-umamulher-negra-do-sul-sul>. Acesso em 10 jan. 2021.

CARNEIRO, Sueli; SANTOS, Tereza. Mulher negra. São Paulo: Nobel/Conselho Estadual da Condição Feminina, 1985.

COLLINS, Patricia Hill. Pensamento feminista negro: conhecimento, consciência e a política do empoderamento. Trad. Jamile Pinheiro Dias. São Paulo: Boitempo, 2019. p. 13.

COLLINS, Patricia Hill. Se perdeu na tradução: feminismo negro, interseccionalidade e política emancipatória. PARÁGRAFO. JAN/JUN. 2017 V.5, N.1 (2017) - ISSN: 2317-4919. Acesso em: dezembro de 2019.

COLLINS, Patricia Hill. Aprendendo com a outsider within. Revista Sociedade e Estado Volume 31 Número 1 Janeiro/Abril 2016. Acesso em: dezembro de 2019.

COLLINS, Patricia Hill. Em Direção a uma nova visão: raça, classe e gênero como categorias de análise e conexão. In: MORENO, Renata (Org.). Reflexões e práticas de transformação feminista. São Paulo: SOF, 2015.

CRENSHAW, Kimberlé Williams. The first decade: critical reflections of "a foot in the closing door." In: UCLA Law Review, v. 49, No. 5, Jun. 2002. Disponível em: $<$ https://is.gd/Jur0063> <http://www2.law.columbia.edu/fagan/courses/law_socialscience/documents/Spring_2 006/ 
Origins\%20of\%20Social\%20Science\%20Law/Crenshaw_Foot\%20in\%20the\%20Clo sing\%20Door.pdf>. Acesso em: 31 jan. 2021.

GALVANI, Giovanna. "O Brasil ainda me dá esperança", declara Angela Davis... CartaCapital, 22 out. 2019. Disponível em<https://is.gd/Imprensa096> ou <https://www.cartacapital.com.br/sociedade/o-brasil-ainda-me-daesperanca-declara-angela-davis/>. Acesso em 31 jan. 2021.

KENNEDY, Duncan; KLARE, Karl. E. A Bibliography of Critical Legal Studies. In: The Yale Law Journal, v. 94, No. 2, Dec. 1984, p. 461-490. Disponível em: <http://www.duncankennedy.net/documents/Photo\%20articles/A\%20Bibliography\%20 of\%2 0cls.pdf>. Acesso em: 31 jan. 2021.

NERIS, Natália. Um efeito alquímico: sobre o uso do discurso dos direitos pelas/os negras/os. Revista Direito e Práxis. Vol. 9, n. 1, Rio de Janeiro; Jan./mar. 2018. Disponível em <https://is.gd/Jur0061> ou <https://doi.org/10.1590/2179-8966/2017/25487>. Acesso em 31 jan. 2021.

PONTES, Ana. Fontes do direito e o processo histórico de silenciamento das mulheres: reinvenção do direito e não subalternização. In: FERRAZ, Carolina Valença (coord.). Manual jurídico feminista. São Paulo: Casa do Direito (Letramento), 2019. p. 117-170.

RIBEIRO, Matilde. Mulheres negras brasileiras: de Bertioga a Beijing. Revista Estudos Feministas. Ano 3, 2. sem. 1995, N. 2/1995, p. 451.

WILLIAMS, Patricia J. Alchemical Notes: Reconstructing Ideals from Deconstructed Rights. In: Harvard Civil Rights - Liberties Law Review. V. 22, No. 2, Spring 1987.

WILLIAMS, Patricia J. The Alchemy of Race and Right: diary of a law professor. Cambridge: Harvard University Press, 1991.

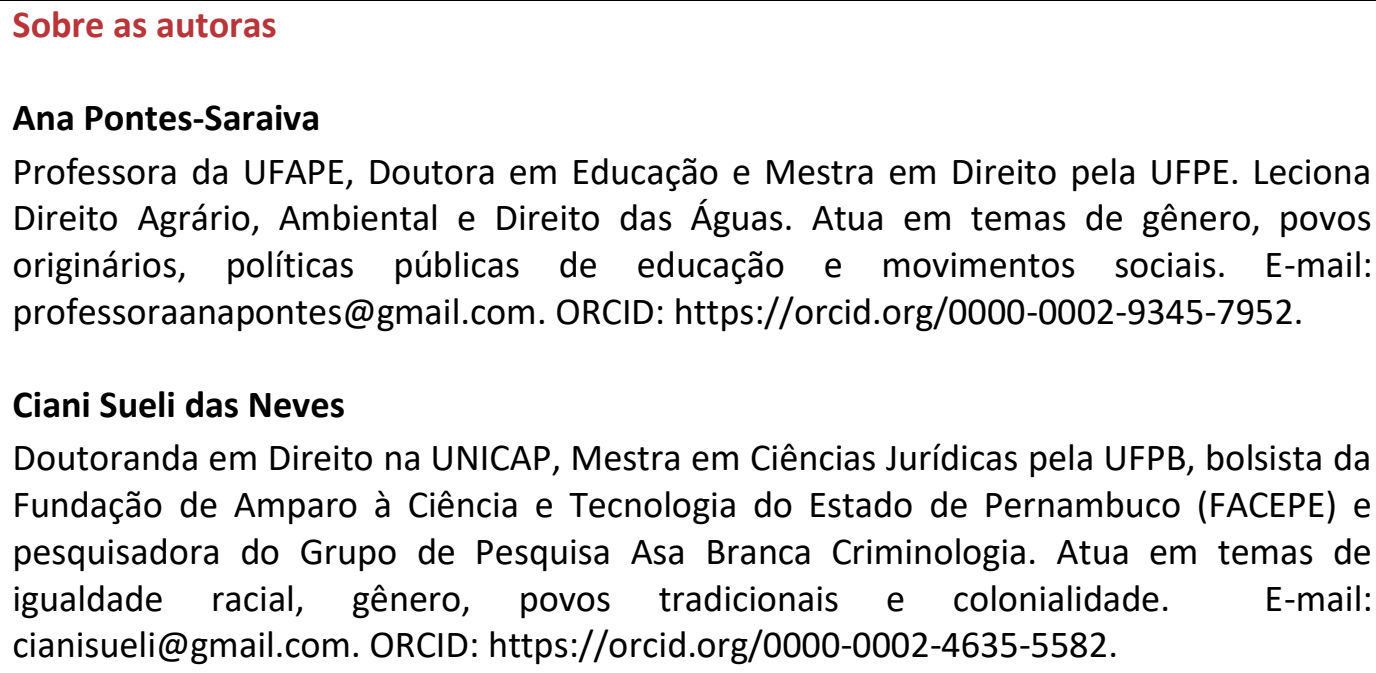

\section{Ciani Sueli das Neves}

Doutoranda em Direito na UNICAP, Mestra em Ciências Jurídicas pela UFPB, bolsista da Fundação de Amparo à Ciência e Tecnologia do Estado de Pernambuco (FACEPE) e pesquisadora do Grupo de Pesquisa Asa Branca Criminologia. Atua em temas de igualdade racial, gênero, povos tradicionais e colonialidade. E-mail: cianisueli@gmail.com. ORCID: https://orcid.org/0000-0002-4635-5582.

As autoras contribuíram igualmente para a redação do artigo. 